\title{
Malignant Soft Tissue Tumor of Uncertain Differentiation
}

National Cancer Institute

\section{Source}

National Cancer Institute. Malignant Soft Tissue Tumor of Uncertain Differentiation. NCI

Thesaurus. Code C6588.

A malignant soft tissue tumor in which the line of differentiation is uncertain. 